IJAMSR 3 (4) www.ijamsr.com CrossRef: https://doi.org/10.31426/ijamsr.2020.3.4.3213

\title{
Review On Graphene Quantum Dots: A Bioimaging Probe
}

Payel Mukherjee ${ }^{1 *}$, Arindam Chakraborty ${ }^{2}$, Dr. Manas Chakraborty ${ }^{2}$

${ }^{1}$ Gurunanak Institute Of Pharmaceutical Science And Technology, Kolkata, India

${ }^{2}$ Calcutta Institute Of Pharmaceutical Technology And AHS, Howrah, West Bengal, India

Email: pmukherjee832@gmail.com

\section{Keywords:}

Graphene quantum dots,

Nano-hybrids,

Biomedical field,

Cytotoxicity,

Bio-imaging.

\begin{abstract}
A B S T R A C T
Graphene quantum dots (GQDS) are nano-hybrid materials, they have gained tremendous interest in biomedical field, especially in Bioimaging due to their unique, stable and tunable photoluminescence, outstanding biocompatibility, low cytotoxicity, low cost, tiny sizes, high stability and exceptional physicochemical characteristics. In this review we are aiming to provide the insights of evolving development of the material's synthetic, characteristics and most importantly Bioimaging properties. We are hoping that this could be beneficial to some extent.
\end{abstract}

Citation: Payel Mukherjee, Arindam Chakraborty, Dr. Manas Chakraborty (2020). Review On Graphene Quantum Dots: A Bioimaging Probe. International Journal of Advanced Multidisciplinary Scientific Research (IJAMSR) ISSN:2581-4281, 3 (4), April, 2020, Pp 27- 42

\section{INTRODUCTION}

Graphene quantum dots (GQDs) belongs to the graphene family and it is defined as zero dimensional luminescent nanomaterial with characteristics derived from both graphene and quantum dots ${ }^{[1-3]}$. Graphene quantum dots are the new rising star in the fluorophore family and has attracted tremendous interest due to its unique and superior physico-chemical properties, large surface area, great mechanical strength, excellent mechanical stability and 
IJAMSR 3 (4) www.ijamsr.com CrossRef: https://doi.org/10.31426/ijamsr.2020.3.4.3213

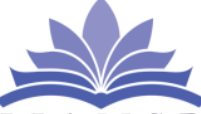

\section{International Journal of}

I J A M S R

Advanced Multidisciplinary Scientific Research (IJAMSR) ISSN:2581-4281

outstanding carrier transport mobility. This has been widely used for optoelectronic devices, energy storage and in drug delivery as well ${ }^{[4-7]}$. Graphene quantum dots have a great thermal and electrical conductivity due to the presence of $\pi$ to $\pi$ bonds below and above the atomic plane. GQDs is having quantum confinement effect and various densities and sp2 site natures, make them optically active and dependent on the size so that the size of the graphene quantum dot consume the energy band gap. Graphene quantum dots have a promising future in biomedical field especially in in-vitro and in-vivo bioimaging . Graphene quantum dots can be a great Bioimaging probe for cancer ${ }^{[8]}$.Cancer is one of the deadliest diseases in the world with approximately more than 10 million cases every year $[\mathbf{9 , 1 0 ]}$. Treatment of cancer is very complex and needs targeted therapy. The cancer treatments nowadays are the main thrust of research. Graphene quantum dots can be useful as Bioimaging probe for cancer cell imaging as they have a prolonged Photostability, greater water solubility, low cytotoxicity, excellent biocompatibility and most importantly outstanding Photoluminescent properties. In this review we would like to emphasize the synthesis, characteristics and application and most importantly biomedical applications of graphene quantum dots to improve the knowledge about the nano-star of this era.

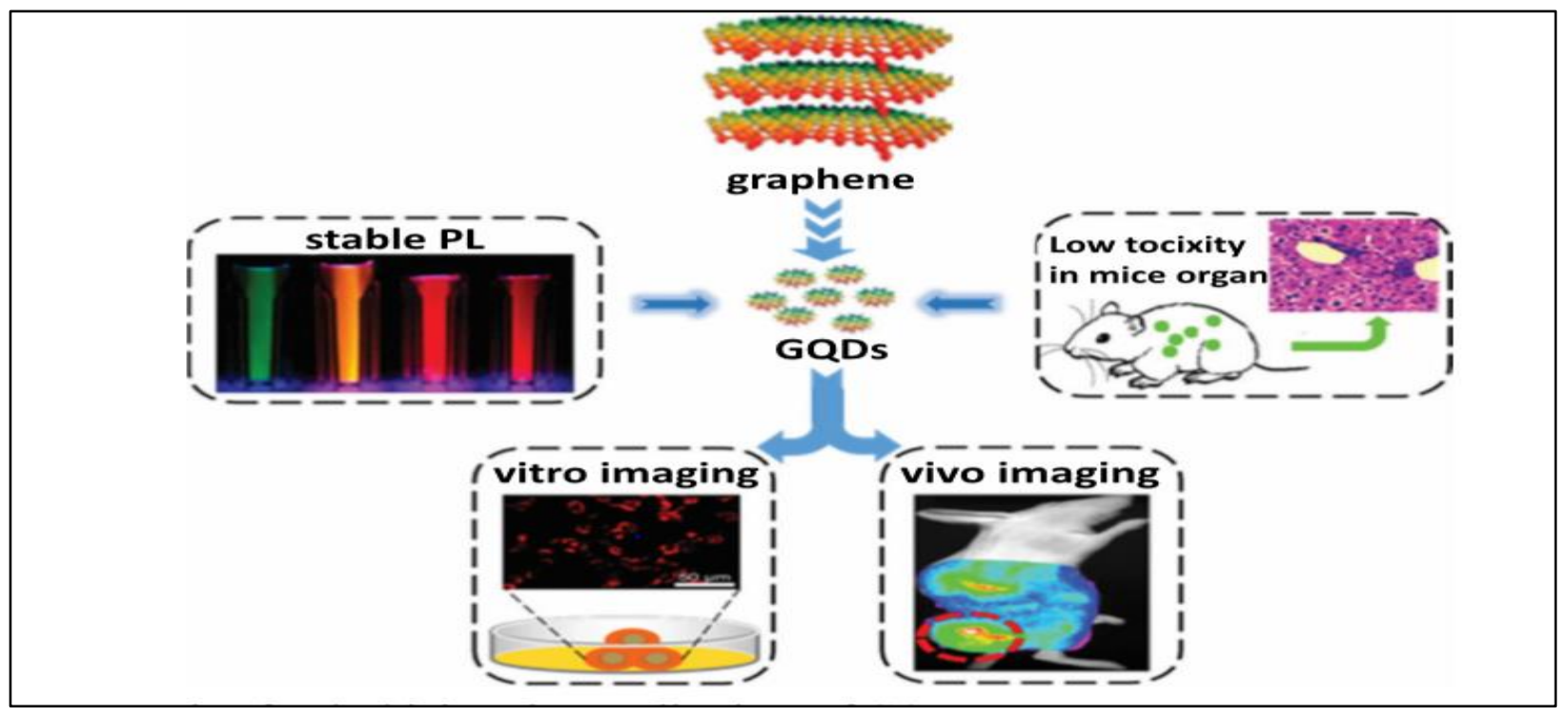

BIOIMAGING APPLICATIONS OF GQDS (Adapted from Li et al ${ }^{[11]}$ ) 
IJAMSR 3 (4) www.ijamsr.com CrossRef: https://doi.org/10.31426/ijamsr.2020.3.4.3213

International Journal of Advanced Multidisciplinary Scientific Research (IJAMSR) ISSN:2581-4281

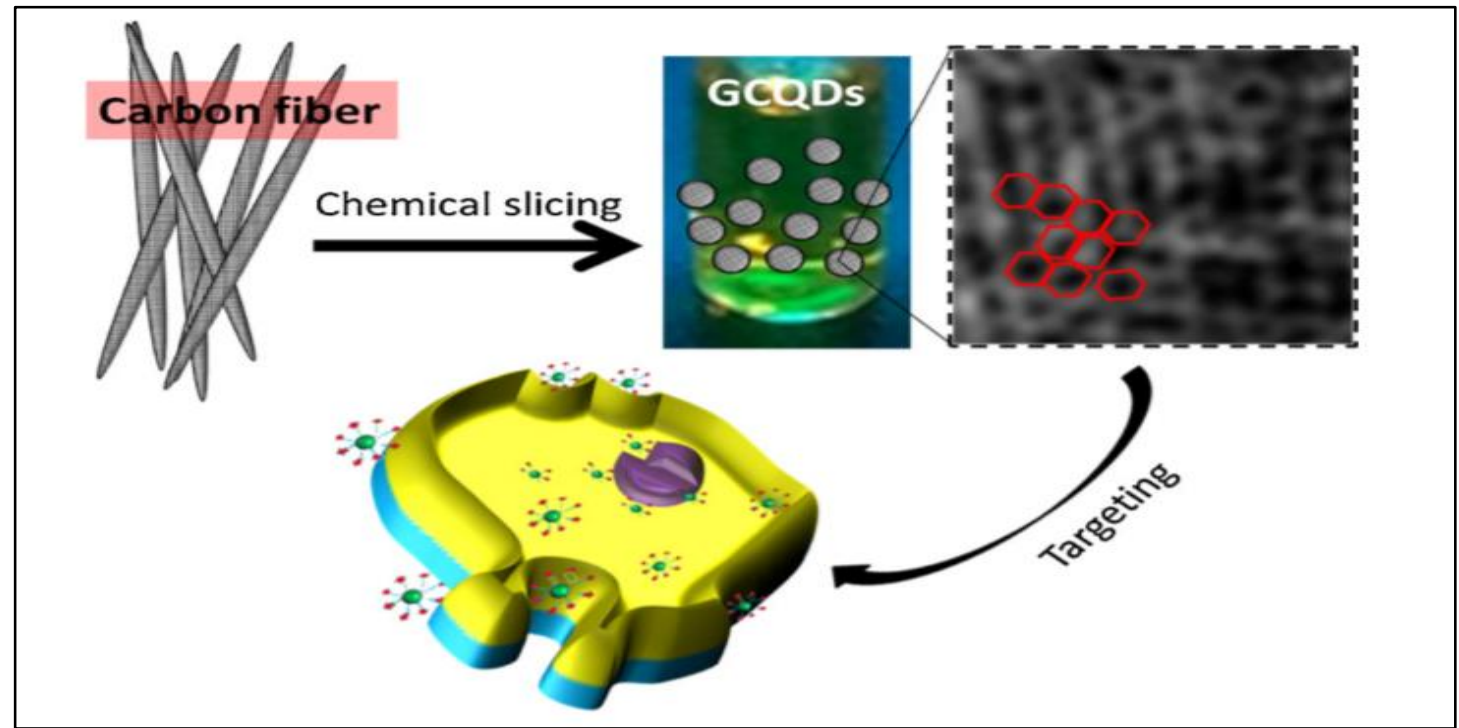

SYNTHESIS AND DIAGRAM APPROACH OF GQDS (Adapted from Aiyer et al $^{[12]}$ )

SYNTHETIC METHODS OF GQDs:

\begin{tabular}{|c|c|c|c|}
\hline METHOD & SUB-DIVISIONS & $\begin{array}{l}\text { STARTING } \\
\text { MATERIALS }\end{array}$ & $\mathrm{SIZE}(\mathrm{nm})$ \\
\hline \multirow{12}{*}{$\begin{array}{l}\text { TOP-DOWN } \\
\text { METHOD }\end{array}$} & \multirow[t]{2}{*}{ Hydrothermal } & Graphene oxide & $5-13$ or $1.5-5$ \\
\hline & & Humic acid & $3-5$ \\
\hline & Solvothermal & Graphene oxide & $\sim 3$ \\
\hline & \multirow[t]{2}{*}{ Microwave assisted } & Graphene oxide & $2-7$ \\
\hline & & Graphite & $2-8$ \\
\hline & \multirow{2}{*}{$\begin{array}{l}\text { Electrochemical } \\
\text { oxidation }\end{array}$} & Graphene film & $3-5$ \\
\hline & & Graphite rod & $5-10$ \\
\hline & Magnetron sputtering & Graphite & $4-12$ \\
\hline & Sono fenton reaction & Graphene oxide & $\sim 5.6$ \\
\hline & \multirow{3}{*}{$\begin{array}{l}\text { Acidic oxidation and } \\
\text { exfoliation }\end{array}$} & Graphene oxide & $5-19$ or $5-25$ \\
\hline & & Carbon black & 15 or 18 \\
\hline & & CFS & $1-4 / 4-8 / 7-11$ \\
\hline
\end{tabular}


IJAMSR 3 (4) www.ijamsr.com CrossRef: https://doi.org/10.31426/ijamsr.2020.3.4.3213

International Journal of

Advanced Multidisciplinary Scientific Research (IJAMSR) ISSN:2581-4281

BOTTOM-UP

METHOD

\begin{tabular}{|l|l|l|}
\hline \multirow{2}{*}{ Precursor pyrolysis } & Citric acid & $\sim 15$ \\
\cline { 2 - 3 } & Glucose & $1.6-2.1$ \\
\hline Solution chemistry & Organic precursors & $\sim 5$ \\
\hline $\begin{array}{l}\text { Catalyzed cage } \\
\text { opening }\end{array}$ & $\mathrm{C}_{60}$ & $2.7-10$ \\
\hline
\end{tabular}

\section{Table no : 1 Synthetic methods for GQDs}

\section{PROPERTIES:}

\section{1) Structure:}

Graphene quantum dots were first synthesized by Pan et al [3]. in 2010 having crystalline structure of single or a few layered graphene. GQDs have dimensions about few nanometres although the largest size reported was about 60 $\mathrm{nm}^{[11]}$. The Shape of the graphene quantum dots are circular, elliptical, triangular, quadrate or hexagonal but circular and elliptical are the shapes of most graphene quantum dots. The graphitic in-plane lattice spacing of graphene quantum dots are of $0.18-0.24 \mathrm{~nm}$ and graphitic interlayer spacing are about $0.334 \mathrm{~nm}$ or greater, measured by HETEM or XRD. Graphene quantum dots have high crystallinity.

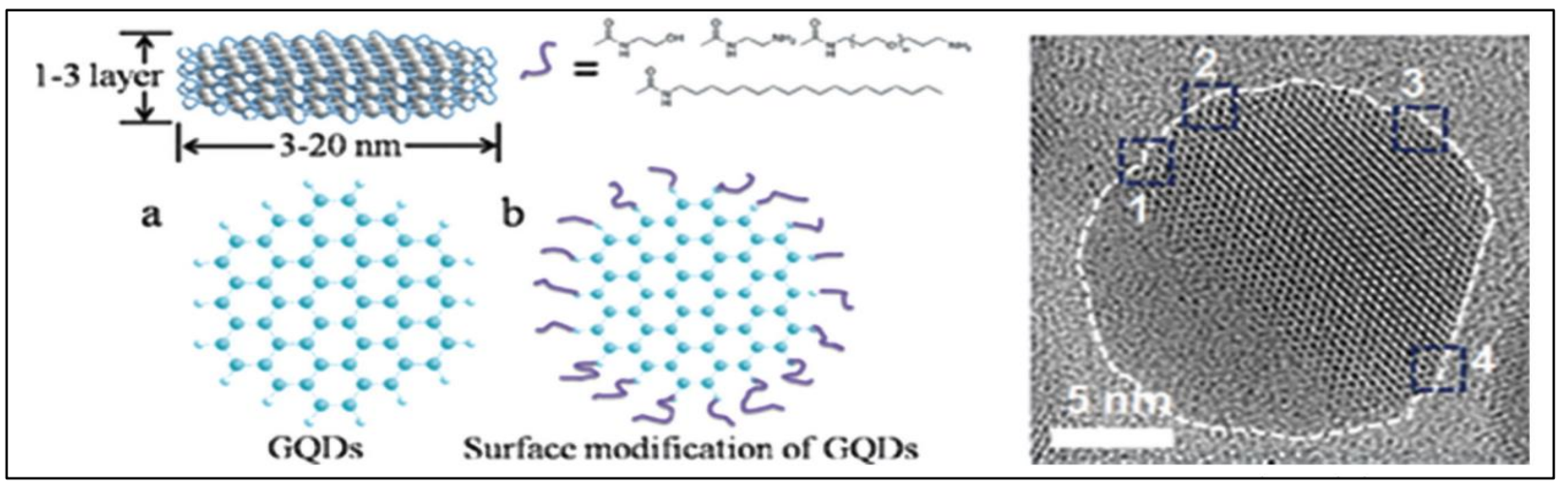

FIGURE 1-A : Structural depiction of GQDs (Adapted from Shen et al $^{[12]}$ ) and B: Zigzag and armchair edges of GQDs (Adapted from Wang et $^{a^{[13]}}{ }^{\text {) }}$ 
IJAMSR 3 (4) www.ijamsr.com CrossRef: https://doi.org/10.31426/ijamsr.2020.3.4.3213

2) Absorption:

Graphene quantum dots show stable absorption bands in the ultraviolet region due to the $\mathrm{n}$ to $\pi^{*}$ transition of $\mathrm{C}=\mathrm{O} \pi$ bonds with an absorption peak at $230 \mathrm{~nm}$ due to $\pi$ to $\pi^{*}$ transition of aromatic $\mathrm{C}=\mathrm{C}$ bonds ${ }^{[\mathbf{1 4 , 1 5}] \text {. }}$

\begin{tabular}{|c|c|}
\hline Factor & Effect of Absorption \\
\hline \hline Size & Absorption peak position red shift \\
\hline $\mathrm{pH}$ & Absorption band change \\
\hline $\begin{array}{c}\text { Surface } \\
\text { chemistry }\end{array}$ & $\begin{array}{c}\text { Absorption peak position red shift, and the } \\
\text { absorption band broaden }\end{array}$ \\
\hline
\end{tabular}

Table no : 2 Factors affecting Absorption

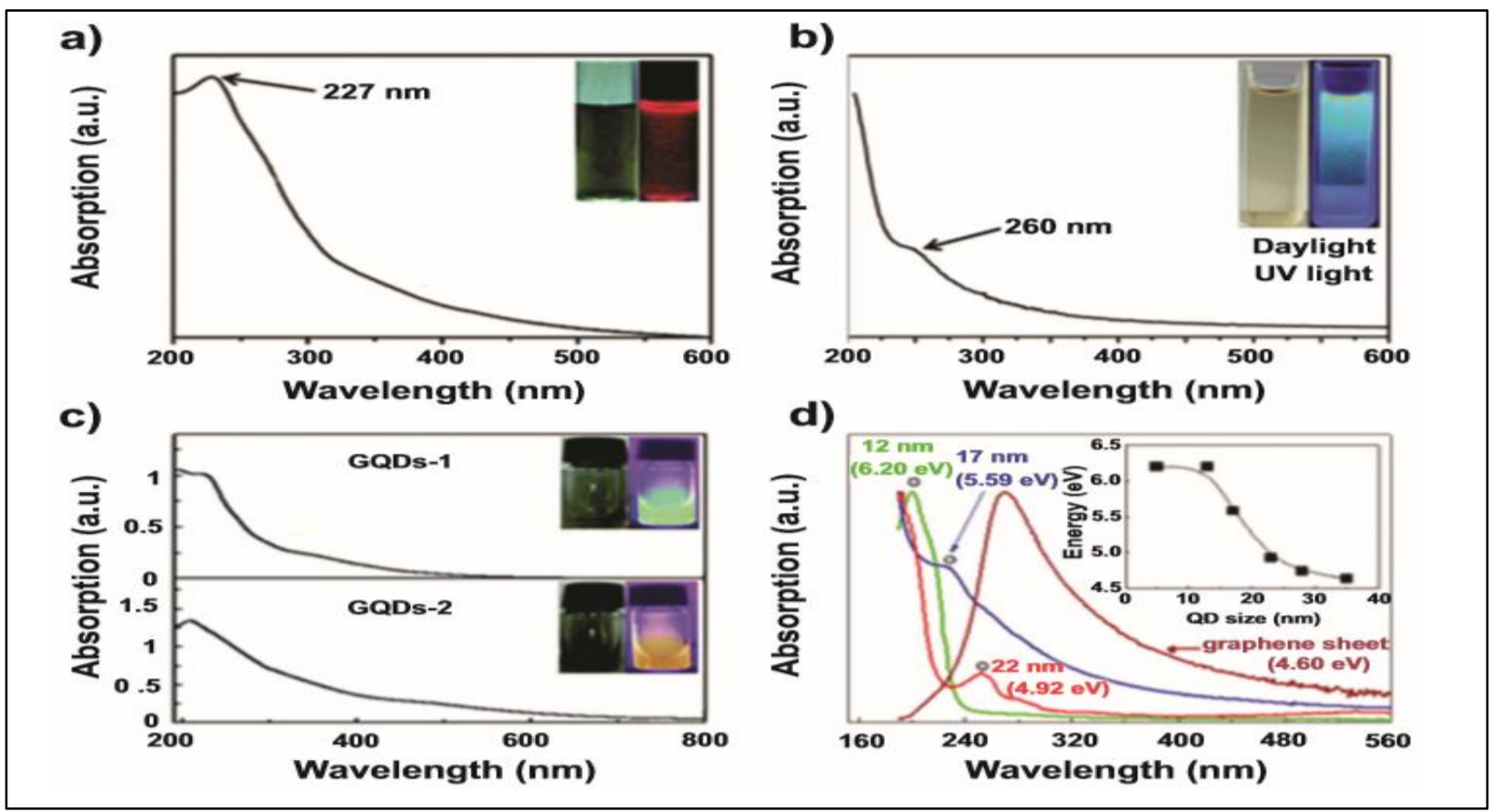

FIGURE 2-a) UV-vis absorption spectrum of GQDs aqueous solution (Adapted from Tan et al ${ }^{[15]}$ ) . b) UVvis absorption spectrum of GQDs from humic acid (Adapted from Shi et $\mathrm{al}^{[17]}$ ). c) UV-vis absorption spectrum of GQDs in water solution(Adapted from Dong et $\mathrm{al}^{[18]}$ ). d) UV-vis absorption spectra of three typical GQDs with average sizes of 12, 17, and $22 \mathrm{~nm}$ dispersed in water (Adapted from Kim et al ${ }^{[16]}$ ) 
IJAMSR 3 (4) www.ijamsr.com CrossRef: https://doi.org/10.31426/ijamsr.2020.3.4.3213

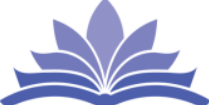

\section{International Journal of \\ Advanced Multidisciplinary Scientific Research (IJAMSR) ISSN:2581-4281}

3) Photoluminescence (PL) :

Photoluminescence is one of the fascinating and important features of graphene quantum dots. The mechanism behind the photoluminescence can be derived from intrinsic state emission and defect stage emission.

\begin{tabular}{|c|c|}
\hline Factors & Effect of PL \\
\hline \hline Size & $\begin{array}{c}\text { Different size exhibit different } \\
\text { fluorescent colors }\end{array}$ \\
\hline Functionalization & $\begin{array}{c}\text { Show different fluorescent colors } \\
\text { compare with pure gqds }\end{array}$ \\
\hline Chemical doping & Enhance the PL intensity \\
\hline pH & $\begin{array}{c}\text { Strong acidic circumstances would } \\
\text { cause the fluorescence attenuation }\end{array}$ \\
\hline Solvent medium & $\begin{array}{c}\text { Different solvents show different } \\
\text { fluorescent colors }\end{array}$ \\
\hline
\end{tabular}

Table no : 3 Factors affecting Photoluminescence
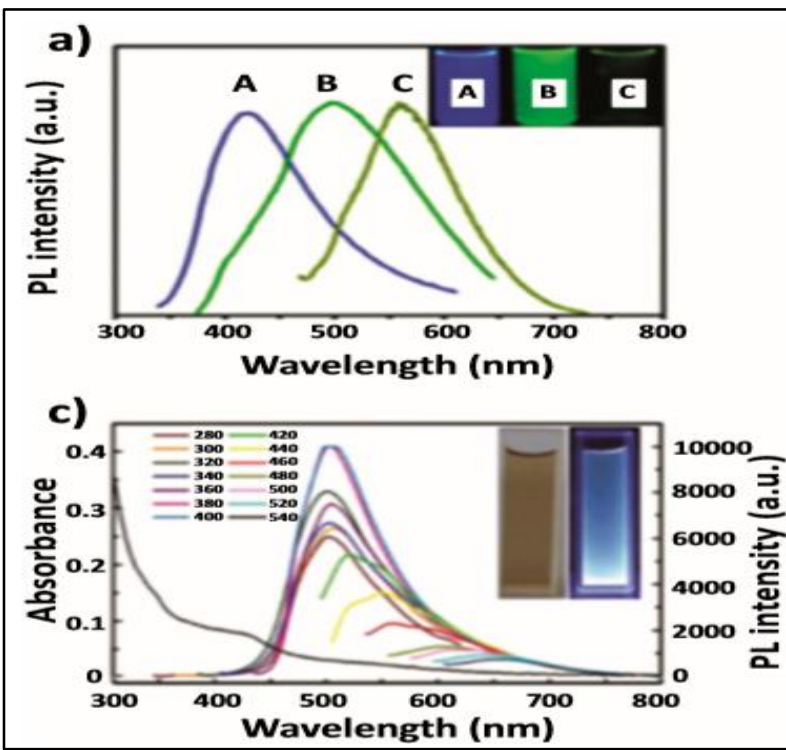
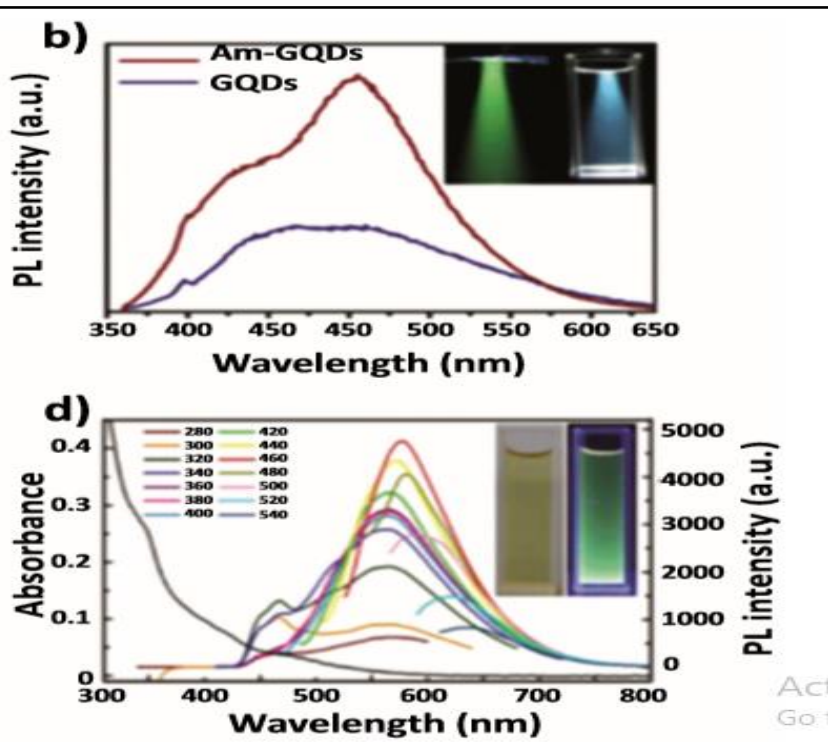

FIGURE 3-a) PL spectra of GQDs with different emission color excited at 318, 331, and $429 \mathrm{~nm}$, respectively(Adapted from Peng et $a l^{[19]}$ ). b) Comparison of PL spectra of GQDs and Am-GQDs for the same concentration, at $350 \mathrm{~nm}$ excitation (Adapted from Suryawanshi et $^{\mathrm{al}} \mathrm{l}^{[20]}$ ). c) PL spectra of HMSGQDs and d) PL spectra of SGQDs (Adapted from Dong et $a l^{[21]}$ ). 
IJAMSR 3 (4) www.ijamsr.com CrossRef: https://doi.org/10.31426/ijamsr.2020.3.4.3213

\section{4) Cytotoxicity}

\section{a) In-vitro Cytotoxicity Test:}

This is very necessary to evaluate the cytotoxicity of the graphene quantum dots as they have applications in Bioimaging. Cytotoxicity can be affected by two factors, mainly size and concentration of graphene quantum dots. Graphene quantum dots having suitable concentration and ultra small size can be accessed from the in vitro experiments. Jiang et al has reported that they have assessed the cytotoxicity test via several techniques like CCK-8 assay, lactate dehydrogenase release (LDH) assay and reactive oxygen species (ROS) assay.

According to CCK-8 assay, cell viability decreases with increase in graphene quantum dot concentration. More than $90 \%$ of the cell viability was obtained at concentration in the range of $21.5-50 \mu \mathrm{g} / \mathrm{ml}$. More than $80 \%$ of the cell viability was observed at the concentration $200 \mu \mathrm{g} / \mathrm{ml}$ which is the highest. From this the fact has proved that graphene quantum dots with low concentrations have great biocompatibility and low toxicity to HeLa cells.
Integrity of cell membrane can be indicated by the LDH level in the cells, which is an indication of cytotoxicity of the cells by LDH assay. Jiang reported that in their work, for 24 hours HeLa cells were exposed to a various graphene quantum dot concentration and LDH release was measured. The result indicates that at the low GQDs concentration, $\mathrm{LDH}$ release levels were a bit higher than the control group indicating that a small fraction of the HeLa cell membrane has been compromised by GQDs. On the other hand, at the high GQD concentration level LDH release level increases about $50 \%$ as compared to control indicating that through endocytosis GQD could enter into the cells and cause membrane damage.

To detect the oxidative stress level in cells, ROS assay is a very effective technique. At low concentration of GQD, ROS level was low, but at high GQD concentration ROS level significantly increases. So from all the results we can say that GQD at low concentration shows low cytotoxicity and at high concentration show relatively high cytotoxicity $[22,23]$. 
IJAMSR 3 (4) www.ijamsr.com CrossRef: https://doi.org/10.31426/ijamsr.2020.3.4.3213
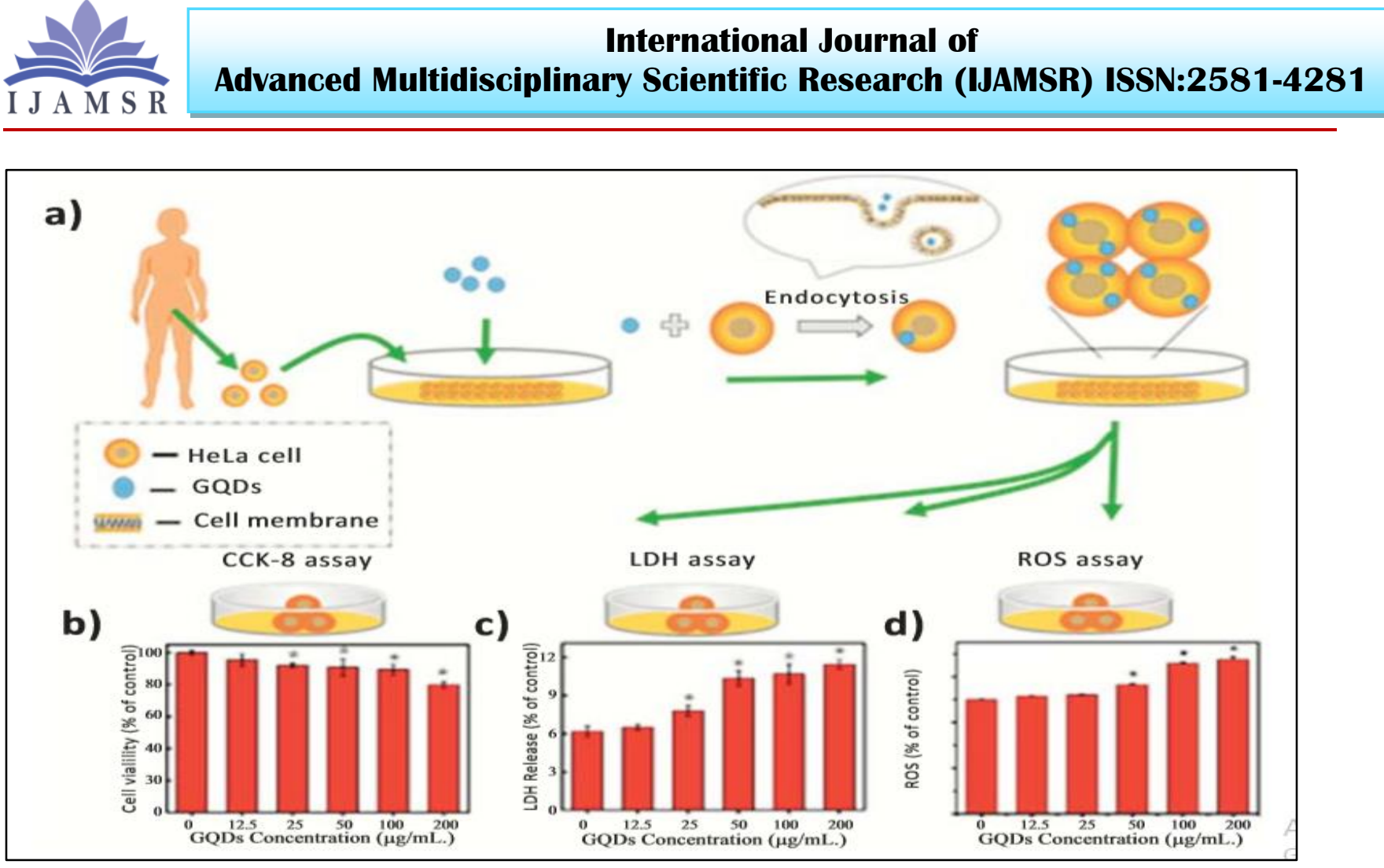

FIGURE 4-a) In vitro experiment of GQDs. b) Cell viability Hela cells incubated with various

concentrations of GQDs for $24 \mathrm{~h}$. c) $\mathrm{LDH}$ release Hela cells incubated with various concentrations of GQDs for $24 \mathrm{~h}$. d) Internal cellular ROS level of Hela cells incubated with various concentrations of GQDs for $24 \mathrm{~h}$. (Adapted from Jiang $e t a l^{[22]}$ )

\section{b) In-Vivo Cytotoxicity Test}

Along with in-vitro cytotoxicity testing it is very necessary to test the cytotoxicity nature in in-vivo system as well. Wang et al has reported that the embryonic development of zebrafish has been affected by graphene quantum dots. For cytotoxicity testing the embryos of zebrafish when exposed to different concentrations of GQDs several malformation have been observed in the zebra fish when they are exposed to the highest GQDs concentration i.e. $200 \mu \mathrm{g} / \mathrm{ml}$. Control group had shown no significant changes as compared to the treatment groups from which we can say that the fluorescence was mainly distributed in the heart and intestine region of the zebra fish. Indicates that the GQDs were bound in these two regions. When the GQDs level was the highest $(200 \mu \mathrm{g} / \mathrm{ml})$ in the treatment groups the fluorescence intensity was also higher in heart and intestine, indicating that that GQDs concentration when higher than $50 \mu \mathrm{g} / \mathrm{ml}$ embryonic development has been disrupted by GQDs 
IJAMSR 3 (4) www.ijamsr.com CrossRef: https://doi.org/10.31426/ijamsr.2020.3.4.3213
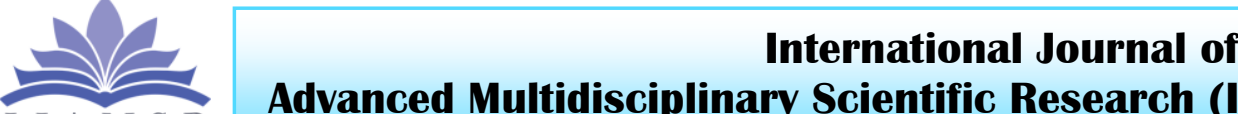

Advanced Multidisciplinary Scientific Research (IJAMSR) ISSN:2581-4281

From so many other tests it can be concluded that i) Graphene quantum dots at low concentration (less than $50 \mu \mathrm{g} / \mathrm{ml}$ ) can be lower in cytotoxicity, ii) if the concentration is higher than $200 \mu \mathrm{g} / \mathrm{ml}$ they can cause cellular death, malformation of organs and even small animals' death also ${ }^{[8] \text {. }}$
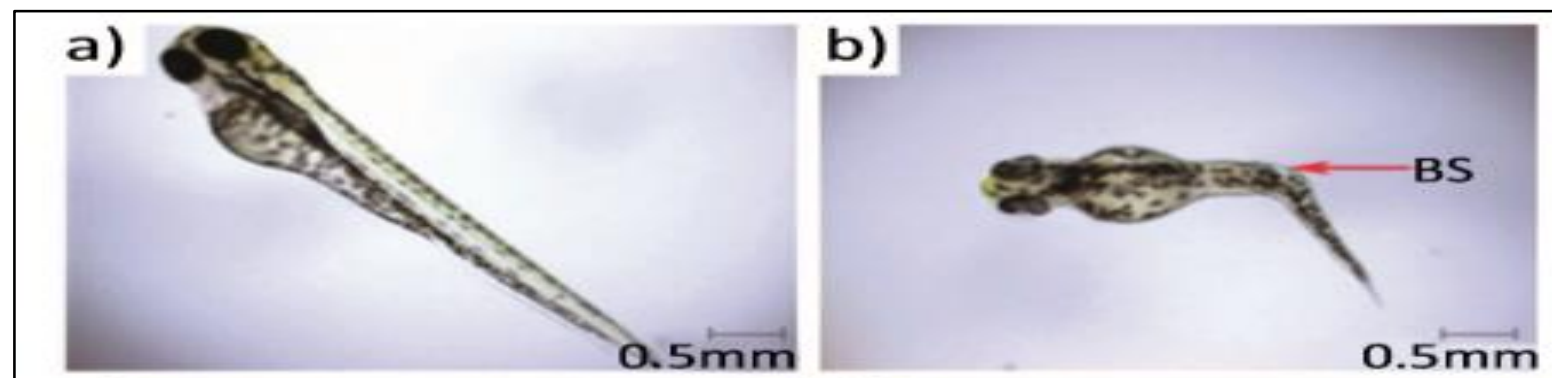

c)

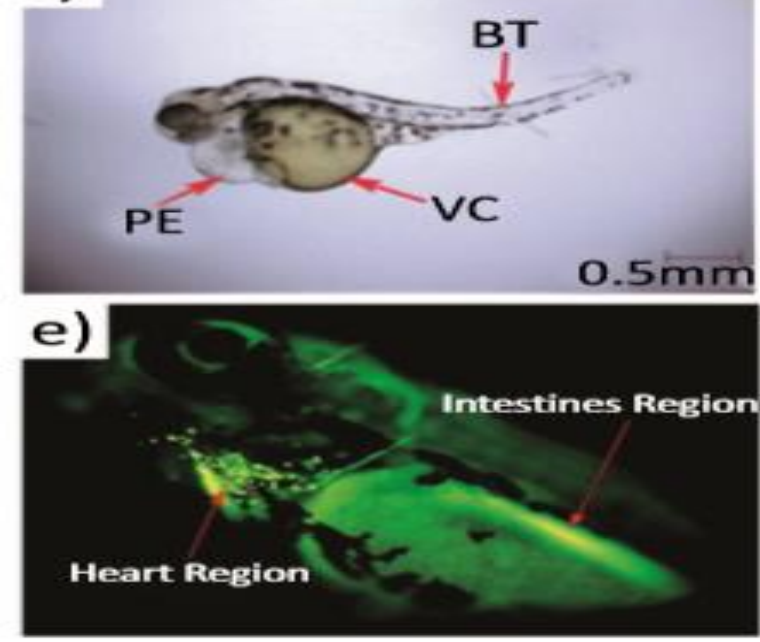

$0.5 \mathrm{~mm}$
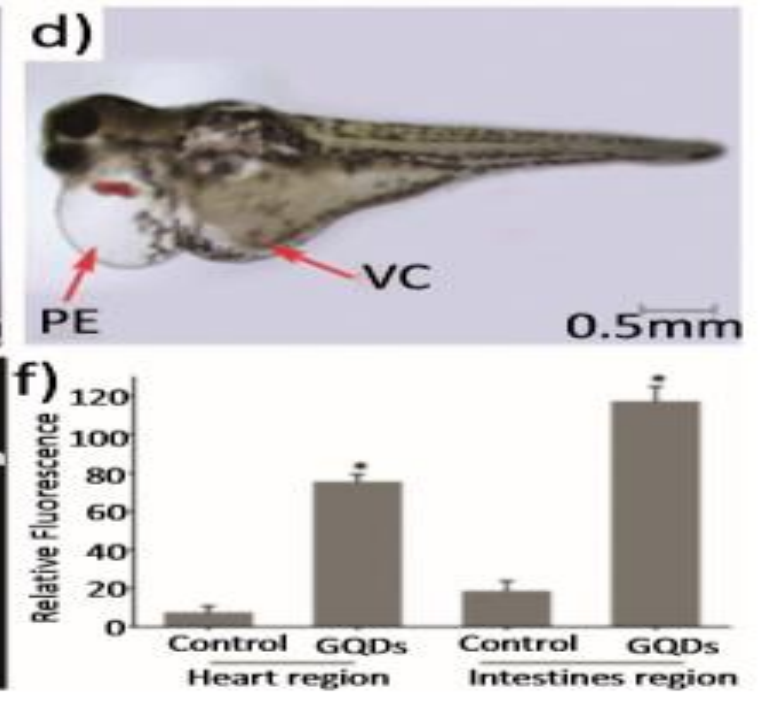

FIGURE 5-a) Normal larvae of zebrafish. b-d) abnormal larvae of zebrafish exposed to $200 \mu \mathrm{g} \cdot \mathrm{mL}-1$ GQDs.

Malformations are indicated by red arrows. e) GQDs uptake by zebrafish larvae at $120 \mathrm{~h}$ post-fertilization. f) Relative fluorescence intensity was significantly elevated compared to control group (Adapted from Wang et $\mathbf{l}^{[8]}$ ).

\section{APPLICATION IN BIOIMAGING:}

Graphene quantum dots having a great application in biomedical field more precisely in bioimaging due to their unique characteristics although this field is in infant stage now but evolution will change the scenario of the bio medical field. 
IJAMSR 3 (4) www.ijamsr.com CrossRef: https://doi.org/10.31426/ijamsr.2020.3.4.3213

\section{a) Cellular Bioimaging:}

Pan et al has reported that GQDs accumulated around HeLa cell's nucleus and after 10 minutes of continuous excitation no photoluminescence reduction happened indicating feasibility for long-term imaging. GQDs can penetrate and label the nucleus without being functionalized with nucleus targeting motif $^{[24]}$.

\section{b) In Vitro Bioimaging Of GQDs:}

GQDs can be used in in-vitro Bioimaging without toxicity. They can be used for stem cell labelling. Zhang et al ${ }^{[25]}$ has prepared a yellow GQDs by a facile electrochemical method for efficient stem cell labelling. For the test three different kinds of stem cells were selected (neurospheres cells, pancreas progenitor cells and cardiac progenitor cells) .They were incubated with GQDs (concentration $25 \mu \mathrm{g} / \mathrm{ml}$ ) for 24 hours at $37^{\circ} \mathrm{C}$ as a result, we can say that GQDs can enter into the cytoplasmic areas of stem cells despite of absorb on the outer surface of the membrane. Further, they reported that GQDs were internalized by stem cells and localized in cytoplasm [26]. Additionally, after treating with GQDs no significant changes were observed in viability, proliferation and metabolic activity of the stem cells.

GQDs which was specially functionalized for cancer cell imaging are now very fascinating in biomedical sciences. Ananthanarayanan has reported that they have used Adenosine triphosphate modified GQDs (ATP-GQDs) for imaging the HeLa cells and real time tracking of transferring receptor in HeLa cells. Cells have taken ATP-GQDs not specifically. But transferrin conjugated GQDs (Tr-GQDs) were segregated near the cell nucleus triggering endocytosis. Fewer fluorescence points were observed when there was excess free transferrin molecules present indicating the binding between transferrin receptors and TrGQDs. In human fibroblasts, Tr-GQDs fluorescence was much weaker than others due to less transferrin receptor in cancer cells. $\mathrm{Tr}$ GQDs/transferrin complexes could quickly endocytosed in the cell membrane ${ }^{[27]}$. 
IJAMSR 3 (4) www.ijamsr.com CrossRef: https://doi.org/10.31426/ijamsr.2020.3.4.3213

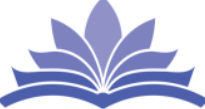

International Journal of

I J A M S R

Advanced Multidisciplinary Scientific Research (IJAMSR) ISSN:2581-4281

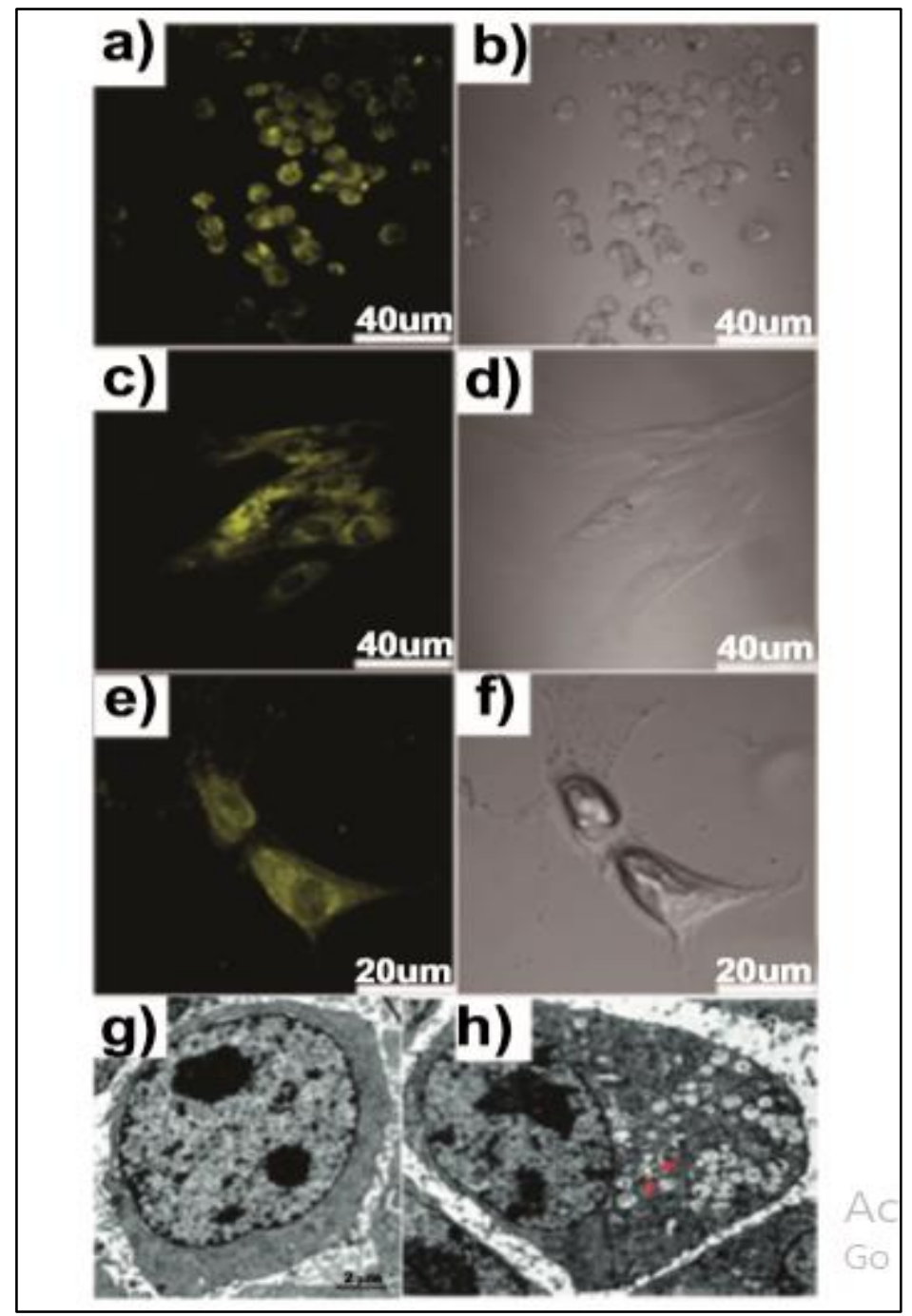

FIGURE 6: a,b) Confocal and bright-field images of neurospheres cells with the fluorescent GQDs. c,d) pancreas progenitor cells. e,f) cardiac progenitor cells. g) TEM image of human neurospheres cells. $h$ ) TEM image of human neurospheres cells after $24 \mathrm{~h}$ incubation with $25 \mu \mathrm{g} / \mathrm{mL}-1$ of GQDs.(a-f adapted from Zhang $e t a l^{[25]}$ and g-h adapted from Shang $e a^{[26]}$ ) 
IJAMSR 3 (4) www.ijamsr.com CrossRef: https://doi.org/10.31426/ijamsr.2020.3.4.3213

\section{International Journal of}

Advanced Multidisciplinary Scientific Research (IJAMSR) ISSN:2581-4281

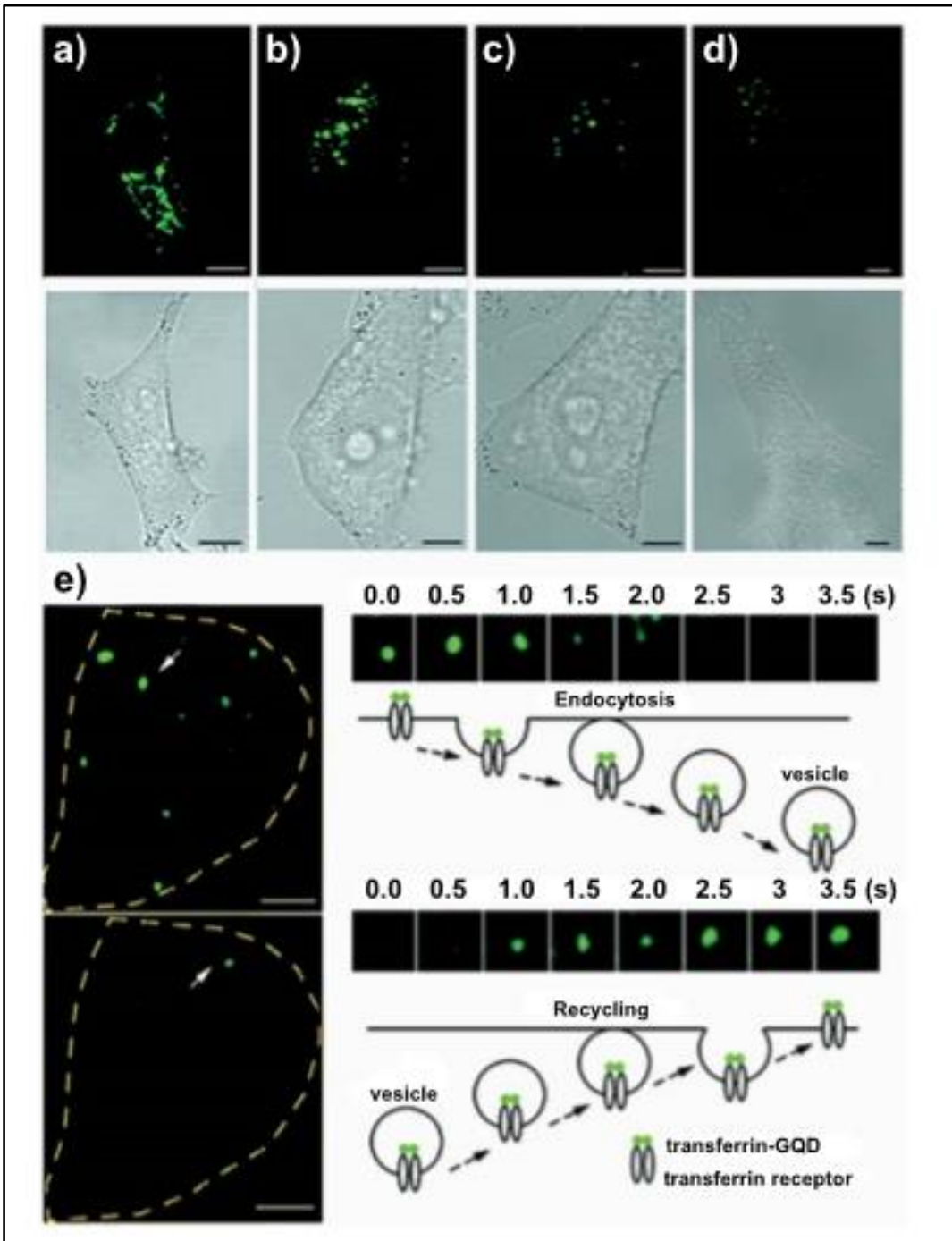

FIGURE 7: a-c) Confocal and bright-field images of HeLa cells labeled with a)ATP-GQDs, b) Tr-GQDs, and c)

Tr-GQDs. d) Confocal and bright-field images of human fibroblast cells labeled with Tr-GQDs. e) TIRFM images of HeLa cells with transferrin receptors labeled with Tr-GQDs (scale bars $=5 \mu \mathrm{m}$ ). Right top: a typical endocytic event of Tr-GQD/transferrin receptor complexes; right bottom: a typical exocytic event of a vesicle containing Tr-GQD/receptor complexes (Adapted from Ananthanarayanan et $\mathrm{l}^{[27]}$ ). 
IJAMSR 3 (4) www.ijamsr.com CrossRef: https://doi.org/10.31426/ijamsr.2020.3.4.3213

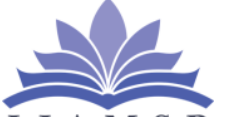

\section{International Journal of \\ Advanced Multidisciplinary Scientific Research (IJAMSR) ISSN:2581-4281}

\section{c) In-Vivo Bioimaging Of GQDs}

In vivo imaging should be done for the graphene quantum dots in animals. Nurunnabi et al ${ }^{[28]}$ has reported that they have injected GQDs at the concentration of 5 and $10 \mathrm{mg} / \mathrm{kg}$ intravenously into the mice to check the time dependent in vivo optical Bioimaging. At 505 $\mathrm{nm}$ no fluorescence response was observed in heart liver or spleen's deeper tissues but after 12 hours of injection fluorescence response was obtained at tumor site indicating that GQDs can be used for superficial tissue imaging but after 24 hours of injection again no response in the fluorescence signal was obtained due to the excretion of the GQDs from the body.

Ge et al ${ }^{[29]}$ has performed a study where they have used three groups of female mice having subcutaneous breast cancer xenografts to observe the capability of GQDs for in vivo Photodynamic therapy (PDT) in the PDT group the GQDs injected to the mice intratumourally and then they were irradiated twice. As a result, after 9 days the tumor was decomposed and after 17 days they were destroyed completely. In contrast, control sample's Bioimaging (C1 and $\mathrm{C} 2)$ indicated that neither the light irradiation nor the GQDs injection alone inhibits the tumor growth.

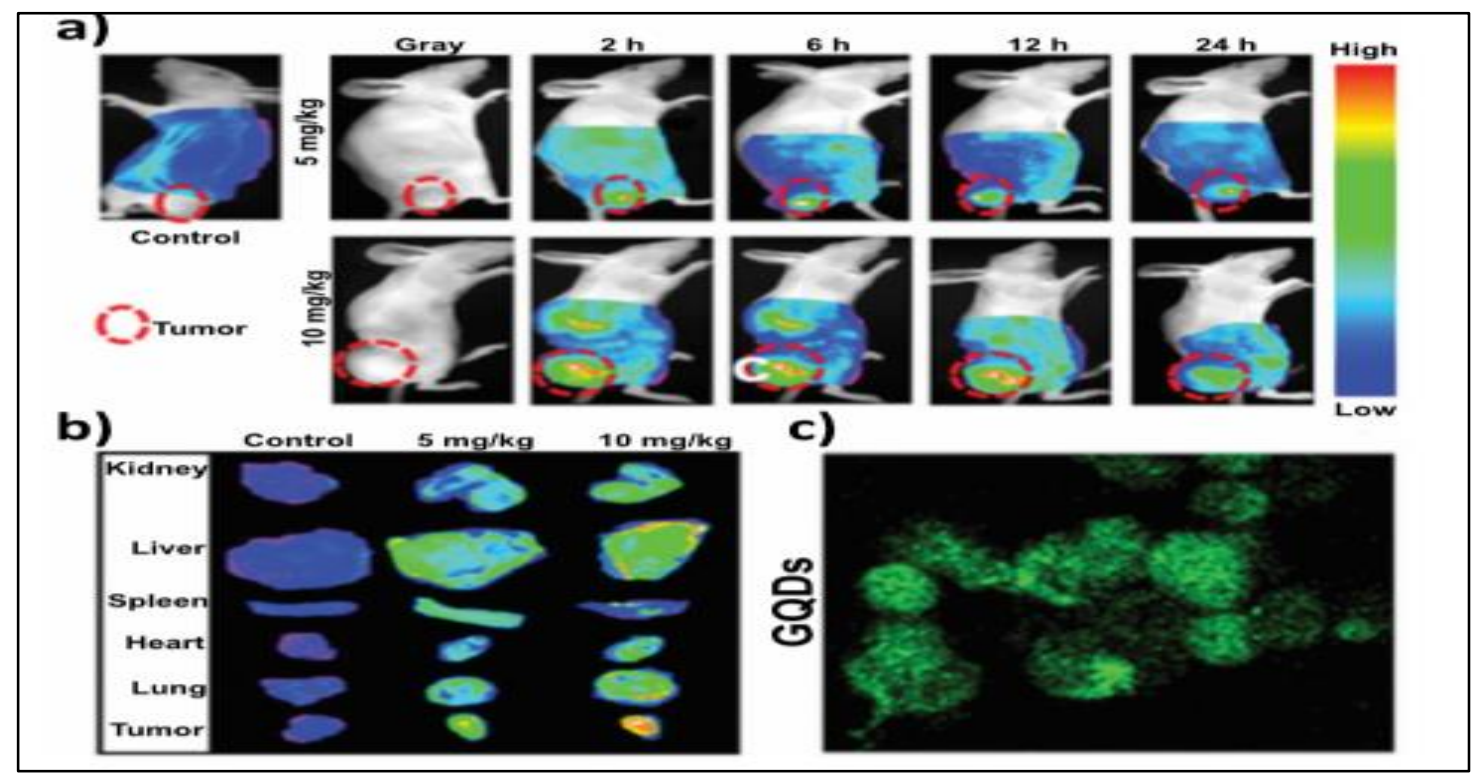

FIGURE 8-a) The in vivo imaging of tumor bearing mice after intravenous injection of GQDs. b) In vivo images of isolated organs of mice at $24 \mathrm{~h}$ after injection of GQDs. c) Confocal laser scanning microscopic (CLSM) images of GQDs (Adapted from Nurunnabi et $l^{[28]}$. 
IJAMSR 3 (4) www.ijamsr.com CrossRef: https://doi.org/10.31426/ijamsr.2020.3.4.3213
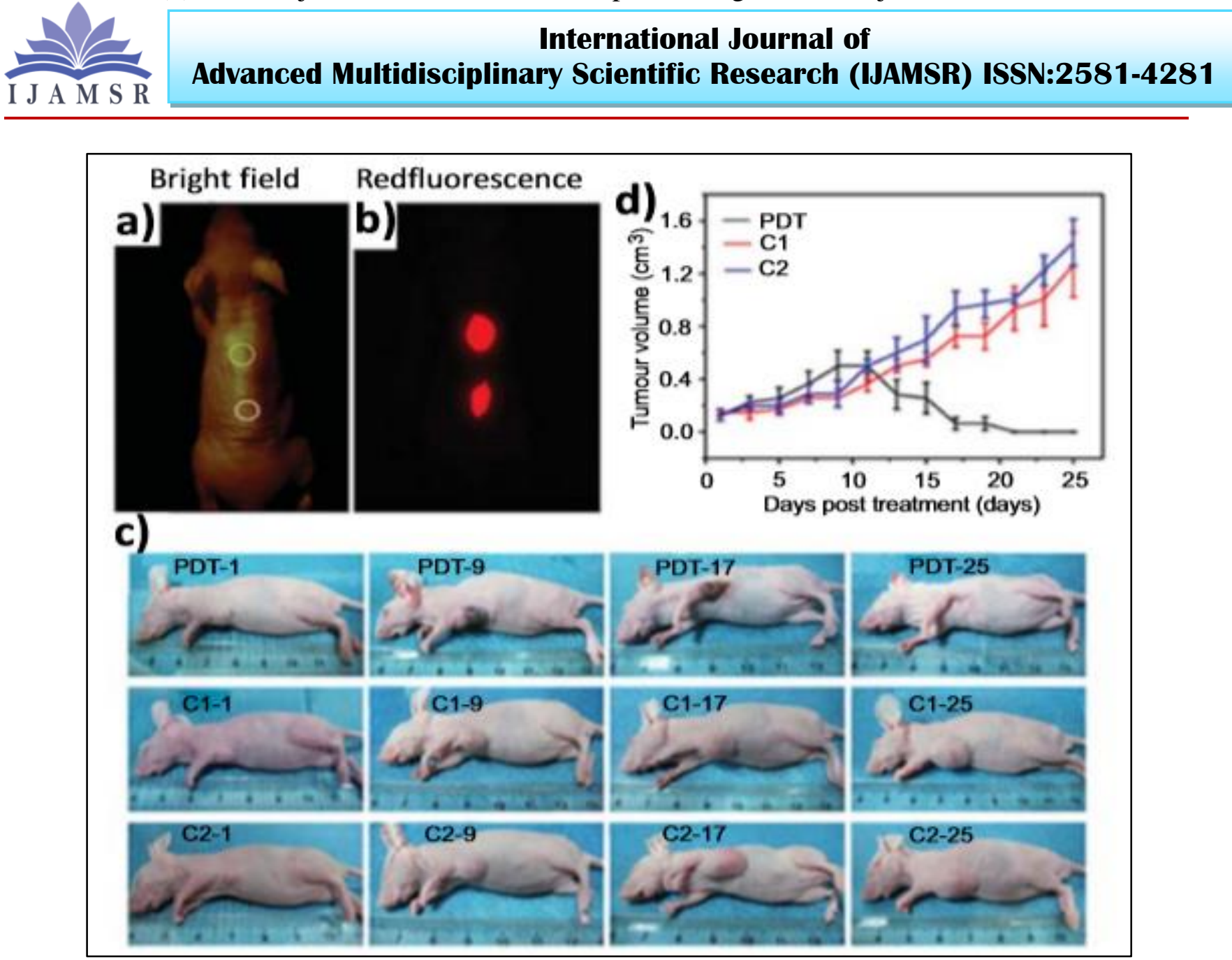

FIGURE 9-a,b) Bright-field image and red-fluorescence image after subcutaneous injection of GQDs in different areas. c) Photographs of mice after various treatment in the 1st, 9th, 17th and 25th day. (PDT: GQDs + light irradiation; C1: GQDs only; C2: light irradiation only) d) Time-dependent tumour growth curves after different treatments (Adapted from Ge et al ${ }^{[29]}$ ).

\section{CONCLUSION:}

As a conclusion, we can conclude that graphene quantum dots are the rising star of nanomaterials nowadays. They have so many unique characteristics like great Photostability, outstanding photoluminescence property, low toxicity, less size as well. The absorption of the graphene quantum dots have been affected by so many factors, photoluminescence of the graphene quantum dots have been affected by so many factors as well, the size of the graphene quantum dots are small and the shape of the graphene quantum dots are various like elliptical, circular etc. The cytotoxicity test has been performed for graphene quantum dots. As a result, we can say that the graphene quantum 
IJAMSR 3 (4) www.ijamsr.com CrossRef: https://doi.org/10.31426/ijamsr.2020.3.4.3213

dots when used in lower concentration (less than $50 \mu \mathrm{g} / \mathrm{ml}$ ) is lower in toxicity, but when its concentration is more than $200 \mu \mathrm{g} / \mathrm{ml}$ the toxicity of the GQDs are higher. As an application the graphene quantum dots are mainly applied in the Bioimaging or it can be applied as Bioimaging probe for cancer cell imaging or cellular Bioimaging. So many stem cells labelling, viability test can be done with graphene quantum dots. But this graphene quantum dots and their applications are in the infant stage so this has so many works to be done in future to change the scenario of the nanomaterials and the biomedical science as well.

\section{References}

1) Lee J, Kim K, Park WI, Kim BH, Park JH, Kim $\mathrm{TH}$, et al. Uniform graphene quantum dots patterned from self-assembled silica nanodots. Nano Lett. 2012;12:6078-83.

2) Shen JH, Zhu YH, Chen C, Yang XL, Li CZ. Facile preparation and upconversion luminescence of graphene quantum dots. Chem Commun. 2011;47:2580-2.

3) Pan DY, Zhang JC, $\mathrm{Li} Z, \quad W u \quad M H$. Hydrothermal route for cutting graphene sheets into blue-luminescent graphene quantum dots. Adv Mater. 2010;22:734-8.

4) Zhao, X.; Zhang, P.; Chen, Y.; Su, Z.; Wei, G. Recent advances in the fabrication and structure-specific applications of graphenebased inorganic hybrid membranes. Nanoscale, 2015, 7, 5080-5093.
5) Zhang, P.; Wang, H.; Zhang, X.; Xu, W.; Li, Y.; $\mathrm{Li}, \mathrm{Q}$; Wei, G.; Su, Z. Graphene film doped with silver nanoparticles: self-assembly formation, structural characterizations, antibacterial ability, and biocompatibility. Biomater. Sci., 2015, 3, 852-860.

6) Zhang, M.; Li, Y.; Su, Z.; Wei, G. Recent advances in the synthesis and applications of graphene-polymer nanocomposites. Poly. Chem., 2015, 6, 6107-6124.

7) Zhang, P.; Huang, Y.; Lu, X.; Zhang, S.; Li, J.; Wei, G.; Su, Z. One-step synthesis of largescale graphene film doped with gold nanoparticles at liquid-air interface for electrochemistry and Raman detection applications. Langmuir, 2014, 30, 8980-8989.

8) Wang, Z.G.; Zhou, R.; Jiang, D.; Song, J.E.; Xu, Q.; Si, J.; Chen, Y.P.; Zhou, X.; Gan, L.; Li, J.Z.; Zhang, H.; Liu, B. Toxicity of graphene quantum dots in zebrafish embryo. Biomed. Environ. Sci., 2015, 28, 341-351.

9) P.Rai , S. Mallidi, X. Zheng , R. Rahmanzadeh , Y. Mir, S. Elrington, A. Khurshid, T. Hasan, Development and applications of phototriggered theranostic agents, Adv. Drug Del. Rev. 62 (2010) 1094.

10) E.J. Hall , D.J. Brenner, Cancer risks from diagnostic radiology , Br.J. Radiol.81 (2008) 362.

11) R. L.Liu , D. Q.Wu , X. L.Feng , K. Mullen , J. Am. Chem. Soc. 2011, 133, 15221.

12) J. Shen, Y. Zhu , X. Yang , C. Li , Chem. Commun. 2012, 48,3686

13). Wang, C . F. Wang, $S$. Chen, Angew. Chem. Int. Ed. 2012, 51, 9297.

14) Lin, L.; Zhang, S. Creating high yield water soluble luminescent graphene quantum dots via exfoliating and disintegrating carbon nanotubes and graphite flakes. Chem. Commun., 2012, 48, 10177-10179.

15) Tan, X.; Li, Y.; Li, X.; Zhou, S.; Fan, L.; Yang, S. Electrochemical synthesis of small-sized red fluorescent graphene quantum dots as a bioimaging platform. Chem. Commun., 2015, 51, 2544-2546. 
IJAMSR 3 (4) www.ijamsr.com CrossRef: https://doi.org/10.31426/ijamsr.2020.3.4.3213

\section{International Journal of}

16) Kim, S.; Hwang, S.W.; Kim, M.-K.; Shin, D.Y.; Shin, D.H.; Kim, C.O.; Yang, S.B.; Park, J.H.; Hwang, E.; Choi, S.-H.; Ko, G.; Sim, S.; Sone, C.; Choi, H.J.; Bae, S.; Hong, B.H. Anomalous behaviors of visible luminescence from graphene quantum dots: interplay between size and shape. ACS Nano., 2012, 6, 8203-8208.

17) Shi, W.; Fan, H.; Ai, S.; Zhu, L. Preparation of fluorescent graphene quantum dots from humic acid for bioimaging application. New J. Chem., 2015, 39, 7054-7059

18) Dong, Y.; Chen, C.; Zheng, X.; Gao, L.; Cui, Z.; Yang, H.; Guo, C.; Chi, Y.; Li, C. One-step and high yield simultaneous preparation of single- and multi-layer graphene quantum dots from CX-72 carbon black. J. Mater. Chem., 2012, 22, 8764-8766.

19) Peng, J.; Gao, W.; Gupta, B.K.; Liu, Z.; Romero-Aburto, R.; Ge, L.; Song, L.; Alemany, L.B.; Zhan, X.; Gao, G.; Vithayathil, S.A.; Kaipparettu, B.A.; Marti, A.A.; Hayashi, T.; Zhu, J.J.; Ajayan, P.M. Graphene quantum dots derived from carbon fibers. Nano Lett., 2012, 12, 844-849.

20) Suryawanshi, A.; Biswal, M.; Mhamane, D.; Gokhale, R.; Patil, S.; Guin, D.; Ogale, S. Large scale synthesis of graphene quantum dots (GQDs) from waste biomass and their use as an efficient and selective photoluminescence onoffon probe for $\mathrm{Ag}(+)$ ions. Nanoscale, 2014, 6, 11664-11670.

21) Dong, Y.; Dai, R.; Dong, T.; Chi, Y.; Chen, G. Photoluminescence, chemiluminescence and anodic electrochemiluminescence of hydrazidemodified graphene quantum dots. Nanoscale, 2014, 6, 11240-11245

22) Jiang, D.; Chen, Y.; Li, N.; Li, W.; Wang, Z.; Zhu, J.; Zhang, H.; Liu, B.; Xu, S. Synthesis of luminescent graphene quantum dots with high quantum yield and their toxicity study. Plos One, 2015, 10, 1-15.

23) Zheng, X.T.; He, H.L.; Li, C.M. Multifunctional graphene quantum dots-conjugated titanate nanoflowers for fluorescence-trackable targeted drug delivery. RSC Adv., 2013, 3, 24853-24857
24) Y. P. Sun, B. Zhou , Y. Lin, W. Wang , K. A. S. Fernando, P. Pathak, M. J. Meziani , B. A. Harruff , X. Wang , H. F. Wang , P. J. G. Luo , H. Yang , M. E. Kose , B. L. Chen , L. M. Veca, S. Y. Xie , J. Am. Chem. Soc. 2006,128 , 7756

25) Zhang, M.; Bai, L.; Shang, W.; Xie, W.; Ma, H.; Fu, Y.; Fang, D.; Sun, H.; Fan, L; Han, M.; Liu, C.; Yang, S. Facile synthesis of watersoluble, highly fluorescent graphene quantum dots as a robust biological label for stem cells. J. Mater, Chem., 2012, 22, 7461-7467.

26) Shang, W.; Zhang, X.; Zhang, M.; Fan, Z.; Sun, Y.; Han, M.; Fan, L. The uptake mechanism and biocompatibility of graphene quantum dots with human neural stem cells. Nanoscale, 2014, 6, 5799-5806.

27) Ananthanarayanan, A.; Wang, Y.; Routh, P.; Sk, M.A.; Than, A.; Lin, M.; Zhang, J.; Chen, J.; Sun, H.; Chen, P. Nitrogen and phosphorus co-doped graphene quantum dots: synthesis from adenosine triphosphate, optical properties, and cellular imaging. Nanoscale, 2015, 7, 8159-8165.

28) Nurunnabi, M.; Khatun, Z.; Huh K.M.; Park, S.Y.; Lee, D.Y.; Cho, K.J.; Lee, Y.-K. In vivo biodistribution and toxicology of carboxylated graphene quantum dots. ACS Nano., 2013, 7, 6858-6867.

29) Ge, J.; Lan, M.; Zhou, B.; Liu, W.; Guo, L.; Wang, H.; Jia, Q.; Niu, G.; Huang, X.; Zhou, H.; Meng, X.; Wang, P.; Lee, C.S.; Zhang, W.; Han, X. A graphene quantum dot photodynamic therapy agent with high singlet oxygen generation. Nat. Commun., 2014, 5, 4596-4604 